\title{
AUTOMATYCZNY HANDEL NA RYNKACH TOWAROWYCH
}

\section{WSTĘP}

Zgodnie z teorią rynki towarowe różnią się od rynków finansowych, ponieważ są mocniej uwarunkowane fundamentami ${ }^{1}$, przez co wymagaja od handlowca dużej wiedzy o czynnikach cenotwórczych. Jednak w ostatnich latach obserwowana finansyzacja rynków, połączona z rozwojem technologicznym skutkuje wprowadzeniem na rynki surowcowe metod stosowanych na rynkach kapitałowych, tj. automatycznego handlu, co skutkuje przede wszystkim zmianami w ich dynamice i nowej definicji funkcji ceny.

Handel automatyczny to handel z zastosowaniem automatycznego systemu składania zleceń, który eliminuje interwencję człowieka. Do tej grupy zaliczają się zlecenia przekazywane przez systemy komputerowe, np. programy oparte na modelach matematycznych (algorytmiczny trading), jak również utworzone za pomocą funkcjonalności zarządzającej procesem ich składania. Handel ten różni się od handlu manualnego, w którym ta procedura odbywa się za pomocą np. klawiatury, myszy bądź ekranu dotykowego ${ }^{2}$. Artykuł ma na celu dokonanie przeglądu stosowanych metod automatycznego handlu, ze szczególnym uwzględnieniem rynków towarowych. Analizie zostanie również poddana hipoteza o wzroście ich popularności na podstawie zmian w strukturze rynków i ich działaniu obserwowanych od roku 2000.

\section{ZMIANY NA RYNKU TOWAROWYM}

Od początku XXI w. obserwowany jest wzrost znaczenia inwestorów finansowych na rynku pochodnych instrumentów towarowych. Wynikiem tego jest znaczna zmiana w mikrostrukturze rynku, która przejawia się we wzroście wolumenu obrotu na rynkach towarowych, jak również zwiększającej się licz-

\footnotetext{
${ }^{1}$ C. Staritz, B. Tröster, K. Küblböck, Commodity prices, financial markets and development, 9/2013 ÖFSE 2015, s. 1-12.

${ }^{2}$ CME, Manual/Automated Trading Indicator (FIX Tag 1028) http://www.cmegroup.com/ rulebook/files/cme-group-ra1210-5.pdf, CME 2012 [dostęp: 27.12.2016].
} 
bie otwieranych pozycji kontrolowanych przez inwestorów finansowych. Ponadto wydłużeniu ulegaja godziny obrotu oraz szybkość zmian, będące wynikiem wykorzystywania przez inwestorów elektronicznych systemów składania zleceń i szerszego korzystania z usprawnień technologicznych ${ }^{3}$.

\section{Wykres 1}

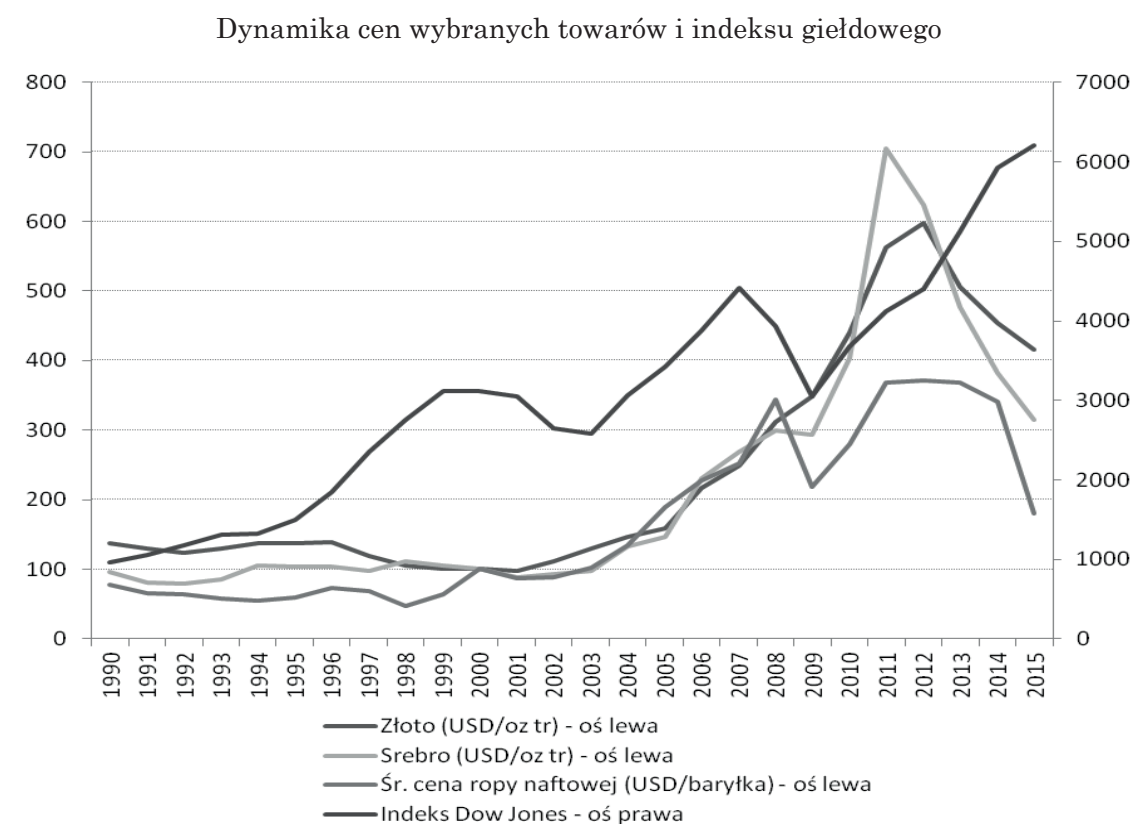

Źródło: opracowanie własne na podstawie danych ze stron unctadstat.unctad.org i stooq.pl.

Raporty Barclays Hedge pokazuja, że w latach 2006-2007 wartość portfeli inwestycji funduszy hedgingowych na rynkach towarowych wzrosła z 90 do 200 mld USD. W tym samym czasie wzrost cen na rynkach towarowych wyniósł $71 \%$ według indeksu CRB (Commodity Research Bureau). Bardziej szczegółowe spojrzenie na rynki towarowe pozwala stwierdzić, że u szczytu bańki spekulacyjnej w 2008 r. fundusze ETF, jak również fundusze hedgingowe (w tym Soros Fund Management), kontrolowały rekordowe 4,51 mld buszli kukurydzy, pszenicy czy soi na rynku kontraktów terminowych na giełdzie CBOT (Chicago Board of Trade). Wart odnotowania jest fakt, że w marcu 2008 r. stanowiło to połowę amerykańskich zapasów ${ }^{4}$.

Badania opublikowane przez Jörga Mayera ${ }^{5}$ pokazuja, że postępująca finansyzacja rynków towarowych prowadzi w ostatnich latach do oderwania cen dóbr

${ }^{3}$ R. Carmona, Financialization of the Commodities Markets: A Non-technical Introduction, Commodities, Energy and Environmental Finance 74, Springer, New York 2015, s. 3-37.

4 Ibidem, s. 3-37.

5 J. Mayer, The growing interdependence between financial and commodity markets, UNCTAD Discussion Papers 195, 2009, s. 1-35. 
notowanych na tych rynkach od teoretycznej relacji między popytem a podażą. Do pozostałych zmian można zaliczyć wzrost liczby produktów inwestycyjnych, a w konsekwencji stosowanych strategii inwestycyjnych, z tendencją wskazującą na rosnące znaczenie strategii aktywnych. Skutkiem tego jest obserwowany wzrost współzależności między rynkiem towarowym a finansowym ${ }^{6}$.

\section{Wykres 2}

Udział handlu automatycznego na CME w latach 2012-2014

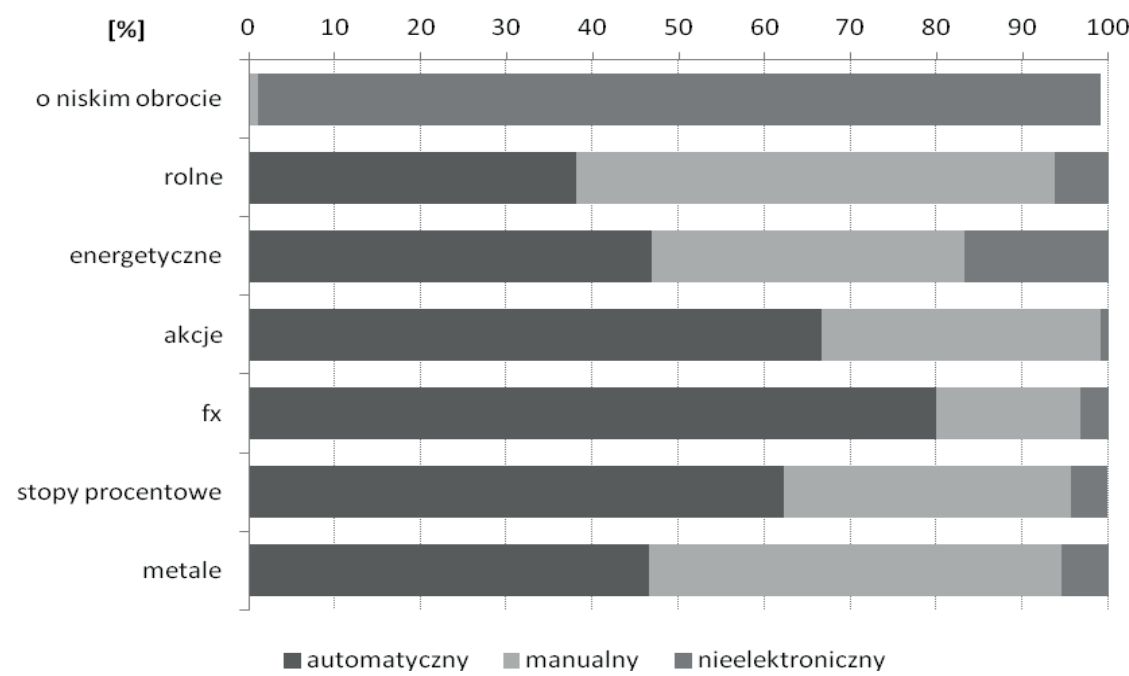

Źródło: opracowanie własne na podstawie R. Haynes, J. Roberts, Automated Trading in Futures Markets, CFTC 2015, s. 1-18.

Zgodnie z badaniami Cornelii Staritz i in. ${ }^{7}$, wzajemne relacje popytu i podaży na dane dobra kształtują obecnie głównie długoterminowe trendy na rynkach towarowych. W krótkoterminowych zmianach cen, szczególnie w odniesieniu do prawdopodobieństwa pojawienia się szczególnie wysokiej zmienności cen, przejawia się obecność i znaczenie inwestorów finansowych. $\mathrm{Z}$ ich działaniami związana jest również rosnacca rola danych makroekonomicznych i powiązań z rynkami finansowymi, które obok popytu i podaży mają znaczący wpływ na kształtowanie cen na rynkach towarowych, co można również zaobserwować na wykresie 1. Można wobec tego oczekiwać, że określanie cen towarów na podstawie danych dotyczących produkcji, zapasów, inwestycji i popytu będzie obarczone stosunkowo dużym błędem, szczególnie w krótkim okresie. Konieczne jest wobec tego poszukiwanie nowej funkcji ceny, na podstawie której możliwe będzie prognozowanie zmian na rynkach towarowych.

${ }^{6}$ C. Heumesser, C. Staritz, Financialisation and the microstructure of commodity markets - a qualitative investigation of trading strategies of financial investors and commercial traders, Working Papers 44, ÖFSE 2013, s. 1-61.

7 C. Staritz, B. Tröster, K. Küblböck, op. cit., s. 1-12. 


\section{Tabela 1}

Udział handlu automatycznego i manualnego w podziale na produkty i podgrupy, w ujęciu podgrupy oraz całej próby (wartości w nawiasach)

\begin{tabular}{|c|c|c|c|c|}
\hline $\begin{array}{c}\text { Grupa produktów } \\
\text { - podgrupa }\end{array}$ & $\begin{array}{c}\text { Liczba } \\
\text { produktów }\end{array}$ & $\begin{array}{c}\text { nieelektro- } \\
\text { niczny (\%) }\end{array}$ & $\begin{array}{c}\text { automatyczny } \\
(\%)\end{array}$ & $\begin{array}{c}\text { manualny } \\
(\%)\end{array}$ \\
\hline Rolne - indeks & 6 & $26,0(0,0)$ & $22,6(0,0)$ & $51,5(0,0)$ \\
\hline Rolne - nabiał & 6 & $4,1(0,0)$ & $6,8(0,0)$ & $89,1(0,0)$ \\
\hline Rolne - zboże i rzepak & 16 & $5,6(0,4)$ & $39,0(2,7)$ & $55,4(3,8)$ \\
\hline $\begin{array}{l}\text { Rolne - żywy } \\
\text { inwentarz }\end{array}$ & 3 & $11,3(0,1)$ & $32,4(0,3)$ & $56,3(0,5)$ \\
\hline Rolne - drewno & 1 & $6,9(0,0)$ & $10,5(0,0)$ & $82,6(0,0)$ \\
\hline $\begin{array}{l}\text { Energetyczne - } \\
\text { biopaliwa }\end{array}$ & 5 & $79,4(0,0)$ & $2,5(0,0)$ & $18,1(0,0)$ \\
\hline Energetyczne - węgiel & 8 & $100,0(0,1)$ & - & - \\
\hline $\begin{array}{l}\text { Energetyczne - ropa } \\
\text { naftowa }\end{array}$ & 22 & $5,5(0,3)$ & $54,3(3,2)$ & $40,2(2,4)$ \\
\hline $\begin{array}{l}\text { Energetyczne - } \\
\text { energia elektryczna }\end{array}$ & 62 & $100,0(0,5)$ & - & - \\
\hline $\begin{array}{l}\text { Energetyczne - ropa } \\
\text { naftowa }\end{array}$ & 40 & $21,2(0,8)$ & $44,2(1,6)$ & $34,6(1,2)$ \\
\hline $\begin{array}{l}\text { Energetyczne - } \\
\text { produkty naftowe }\end{array}$ & 126 & $15,0(0,4)$ & $46,0(1,2)$ & $39,0(1,0)$ \\
\hline $\begin{array}{l}\text { Akcje - } \\
\text { międzynarodowy indeks }\end{array}$ & 4 & $0,4(0,0)$ & $69,3(0,4)$ & $30,3(0,2)$ \\
\hline $\begin{array}{l}\text { Akcje - wybrane } \\
\text { indeksy sektorowe }\end{array}$ & 9 & $18,8(0,0)$ & $59,2(0,0)$ & $22,0(0,0)$ \\
\hline Akcje - US Index & 12 & $0,9(0,2)$ & $66,5(13,8)$ & $32,6(6,8)$ \\
\hline FX - E Micros & 8 & $0,0(0,0)$ & $66,3(0,1)$ & $33,7(0,0)$ \\
\hline FX - rynki wschodzące & 18 & $12,5(0,1)$ & $70,3(0,3)$ & $17,1(0,1)$ \\
\hline $\mathrm{FX}-\mathrm{G} 10$ & 25 & $2,8(0,2)$ & $80,7(5,4)$ & $16,4(1,1)$ \\
\hline $\begin{array}{l}\text { Stopy procentowe - } \\
\text { Swaps z dostawą }\end{array}$ & 4 & $16,3(0,0)$ & $47,8(0,0)$ & $35,9(0,0)$ \\
\hline $\begin{array}{l}\text { Stopy procentowe - } \\
\text { STIR }\end{array}$ & 3 & $2,2(0,5)$ & $60,3(13,0)$ & $37,5(8,1)$ \\
\hline $\begin{array}{l}\text { Stopy procentowe - } \\
\text { Skarbu Państwa (USA) }\end{array}$ & 5 & $5,9(1,5)$ & $64,0(16,6)$ & $30,2(7,8)$ \\
\hline Metale - przemysłowe & 4 & $3,1(0,0)$ & $49,2(0,3)$ & $47,7(0,3)$ \\
\hline Metale-szlachetne & 8 & $6,1(0,1)$ & $45,9(1,1)$ & $48,0(1,1)$ \\
\hline
\end{tabular}

Źródło: opracowanie własne na podstawie R. Haynes, J. Roberts, op. cit. ${ }^{8}$

${ }^{8}$ R. Haynes, J. Roberts, op. cit., s. 5. 
Poza wymienionymi czynnikami, które mogą zostać ujęte w funkcji ceny, istotnym elementem jest również handel algorytmiczny, który wkroczył na rynek towarowy wraz z ich finansyzacja. Opracowanie Commodity Futures Trading Commission ${ }^{9}$ wskazuje na istotną zależność między wykorzystaniem automatycznego handlu a poziomem wolumenu na Chicago Mercantile Exchange. Skalę tego zjawiska dobrze obrazuja dane przedstawione na wykresie 2, gdzie w zależności od rynku handel automatyczny odpowiada za 40-80\% obrotów w latach 2012-2014. Największe znaczenie automatycznych systemów jest dostrzegalne dla instrumentów pochodnych na rynku walutowym (zarówno rynek terminowy, jak i rynek spot (80\%), rynku akcji (67\%) oraz rynku stóp procentowych $(62 \%))$.

Szczegółowe dane dotyczące udziału handlu automatycznego na poszczególnych rynkach, jak również dostępności produktów przedstawiono w tabeli 1 . Warto poddać analizie powyższe dane $\mathrm{w}$ odniesieniu do inwestorów charakteryzowanych ze względu na wolumen transakcji. Zostało to przedstawione $\mathrm{w}$ tabeli 2 . W odniesieniu do przedstawionych danych wpływ drobnych inwestorów, a zatem małych zleceń, jest istotny choćby na rynku kukurydzy. Ponadto zróżnicowanie stosowanych strategii inwestycyjnych obrazowane jest przez udział w poszczególnych grupach inwestorów strategii automatycznych i manualnych (odpowiednio kolumny 3 i 4 oraz 6 i 7).

Tabela 2

Podział handlu automatycznego i manualnego ze względu na produkt i grupę handlowców

\begin{tabular}{|l|r|c|c|c|c|c|}
\hline \multirow{2}{*}{$\begin{array}{c}\text { Nazwa kontraktu } \\
\text { futures }\end{array}$} & \multicolumn{2}{|c|}{$\begin{array}{c}\text { Handlowcy o niskim } \\
\text { wolumenie obrotu* }\end{array}$} & \multicolumn{2}{c|}{$\begin{array}{c}\text { Handlowcy o wysokim } \\
\text { wolumenie obrotu }\end{array}$} \\
\cline { 2 - 7 } & $\begin{array}{c}\text { Liczba } \\
\text { kont } \\
\text { handlo- } \\
\text { wych }\end{array}$ & $\begin{array}{c}\text { Handel } \\
\text { automa- } \\
\text {-tyczny } \\
\text { (\%) }\end{array}$ & $\begin{array}{c}\text { Handel } \\
\text { manual- } \\
\text { ny (\%) }\end{array}$ & $\begin{array}{c}\text { Liczba } \\
\text { kont } \\
\text { handlo- } \\
\text { wych }\end{array}$ & $\begin{array}{c}\text { Handel } \\
\text { automa- } \\
\text {-tyczny } \\
\text { (\%) }\end{array}$ & $\begin{array}{c}\text { Handel } \\
\text { manual- } \\
\text { ny (\%) }\end{array}$ \\
\hline E-mini S\&P 500 & 126675 & 19,2 & 29,3 & 469 & 45,5 & 5,8 \\
\hline E-mini NASDAQ 100 & 52793 & 17,4 & 20,0 & 544 & 58,2 & 4,3 \\
\hline Ropa naftowa & 6541 & 18,4 & 30,5 & 538 & 34,6 & 11,8 \\
\hline $\begin{array}{l}\text { Gaz ziemny (Henry } \\
\text { Hub) }\end{array}$ & 351813 & 15,1 & 24,5 & 649 & 38,5 & 17,5 \\
\hline Eurodolar & 21223 & 14,5 & 30,3 & 619 & 46,1 & 6,9 \\
\hline Obligacje 10-letnie & 47773 & 20,5 & 27,4 & 716 & 42,7 & 5,1 \\
\hline Obligacje 5-letnie & 22399 & 20,0 & 18,7 & 1126 & 47,0 & 6,4 \\
\hline Euro & 45064 & 14,9 & 15,1 & 477 & 64,1 & 3,7 \\
\hline Jen japoński & 29191 & 14,4 & 12,7 & 485 & 66,9 & 3,3 \\
\hline Kukurydza & 7629 & 18,7 & 36,0 & 868 & 18,6 & 20,2 \\
\hline
\end{tabular}

${ }^{9}$ R. Haynes, J. Roberts, op. cit., s. 1-18. 
cd. tab. 2

\begin{tabular}{|l|l|l|l|l|l|l|}
\hline Soja & 59739 & 19,2 & 42,2 & 815 & 17,2 & 15,4 \\
\hline Złoto & 52675 & 19,0 & 31,8 & 630 & 26,9 & 15,8 \\
\hline Srebro & 23934 & 17,0 & 24,4 & 696 & 29,3 & 25,4 \\
\hline
\end{tabular}

* Inwestor o dużym wolumenie to handlowiec, którego udział w dziennym obrocie wynosi co najmniej 0,5\% dla wszystkich terminów wygasania kontraktów.

Źródło: opracowanie własne na podstawie R. Haynes, J. Roberts, op. cit., s. 9.

Dane zaprezentowane $\mathrm{w}$ tabelach 1 oraz 2 pozwalają stwierdzić, że znaczenie automatycznych systemów transakcyjnych zaczyna odgrywać istotna rolę w procesie kształtowania ceny, przy czym wykorzystywanie tego typu rozwiązań przez różne grupy inwestorów wskazuje na różnorodność strategii inwestycyjnych stosowanych na analizowanych rynkach terminowych. Zasadne wydaje się zatem bardziej wnikliwe przeanalizowanie automatów transakcyjnych - warunków rynkowych koniecznych do zaistnienia możliwości wykorzystania automatów, głównych założeń ich działania, realizowanych przez nie strategii, ale również ich efektywności.

\section{GŁÓWNE CZYNNIKI WPŁYWAJĄCE NA ROZWÓJ AUTOMATYCZNEGO HANDLU}

Rozwój automatycznego handlu jest uzależniony od unikatowego połączenia następujących determinant: płynności, która zmniejsza spread pomiędzy oferta kupna i sprzedaży; zmian stanu prawnego, który determinuje, jakie strategie mogą być zastosowane, jak i zwiększa transparentność, a także rozwoju technologii, która określa szybkość, trafność i kosztowe bariery wejścia.

\section{Płynność}

Skuteczność systemów automatycznego handlu zależy w dużym stopniu od płynności rynków, na których mają być stosowane. W związku z tym warto przyjrzeć się opracowaniu $\mathrm{BCG}^{10}$ dotyczącemu płynności 31 analizowanych rynków surowcowych, giełd walutowych, akcji i obligacji jako punktowi odniesienia - rysunek 3 - a tym samym określić rynki, na których handel automatyczny i algorytmiczny może być szczególnie opłacalny. Na wykresie podzielono rynki na pięć kategorii względem kryterium płynności, od niepłynnych do ultrapłynnych. Podział ten jest determinowany w znacznej mierze przez rodzaj zawieranych transakcji, które są charakterystyczne dla danego produktu.

10 The Boston Consulting Group, Hyperliquidity: A Gathering Storm for Commodity Traders, The Boston Consulting Group 2015. 
$\mathrm{Na}$ wielu z poniższych rynków transformacje zachodzą szybko. Zmiany w poziomach płynności mogą wynikać zarówno z wprowadzanych deregulacji (europejski rynek gazu), standaryzacji i wypracowaniu powszechnie akceptowanych wzorców umownych (fizyczne kontrakty na dostawę ropy naftowej i węgiel), wzrostu konkurencji (rynek LNG), rozwoju rynku OZE (europejski rynek energii, w szczególności niemiecki rynek transakcji spot), czy właśnie stosowania algorytmicznych systemów transakcyjnych (kontrakty terminowe na ropę naftową i gaz ziemny).

Schemat 1

Płynność wybranych rynków

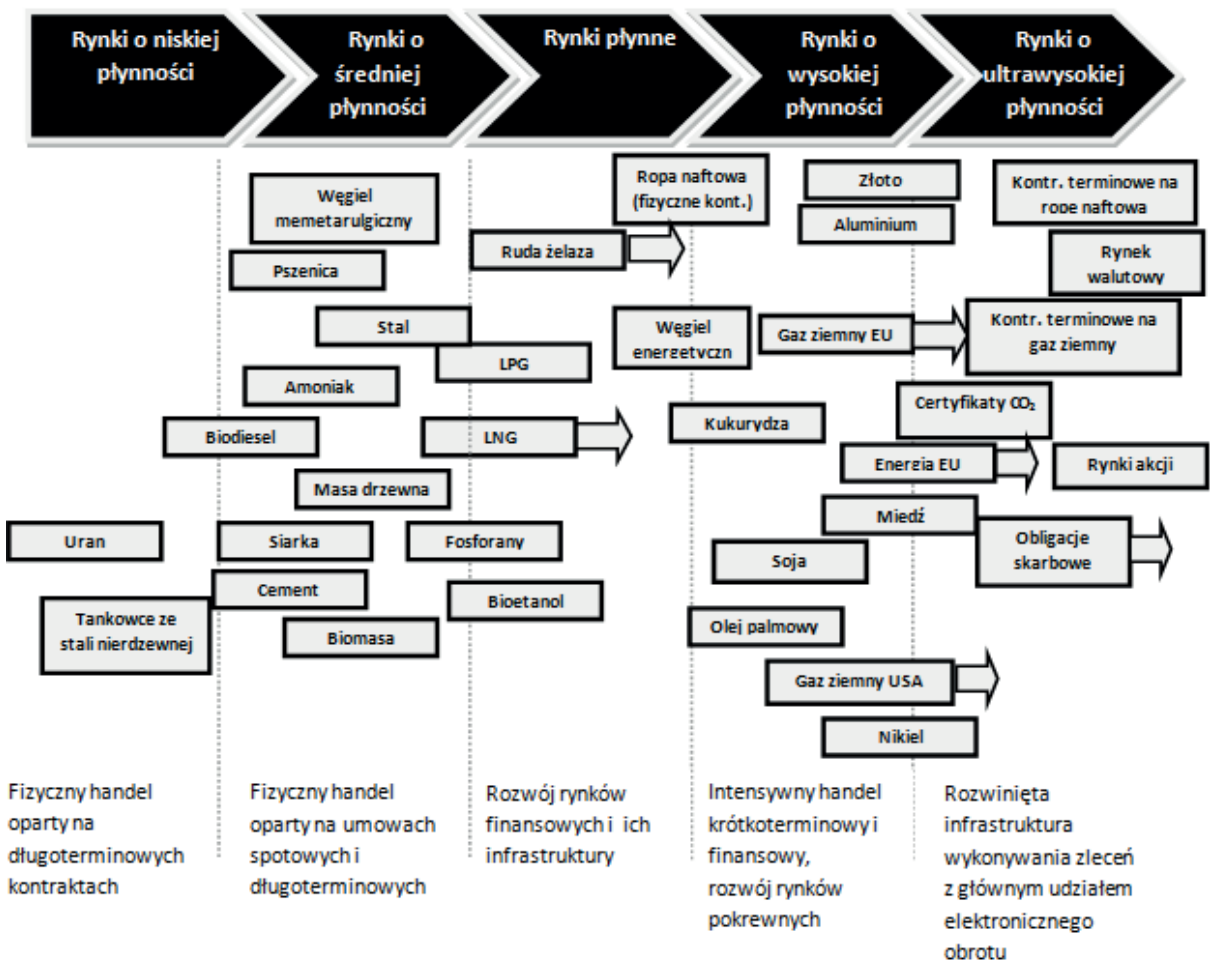

Źródło: opracowanie własne na podstawie danych The Boston Consulting Group ${ }^{11}$.

\section{Uwarunkowania prawne}

Rozwój automatycznego handlu jest często uwarunkowany regulacjami, jakie niosa za sobą zmiany prawne. W ostatnich latach regulatorzy wprowadzają wiele aktów wpływających na przejrzystość rynku i zapewniających uczestnikom odpowiednią ochronę przed nadużyciami.

Jednym z efektów obserwowanych po kryzysie z roku 2008 jest spowolnienie finansyzacji rynków towarowych w wyniku zmian legislacyjnych. Wprowa-

\footnotetext{
11 The Boston Consulting Group, op. cit.
} 
dzone regulacje: Bazylea III ${ }^{12}$, Dodd-Frank Act ${ }^{13}$ - zwiększyły koszty obecności dużych banków inwestycyjnych na rynkach surowców, w porównaniu z okresem przed kryzysem, co poskutkowało znacznym zmniejszeniem ich obecności na tych rynkach. Zgodnie $\mathrm{z}$ badaniami Arina Raya ${ }^{14}$ zyski dziesięciu największych banków zmniejszyły się w 2013 r. o $67 \%$ w porównaniu ze szczytem osiagniętym w $2008 \mathrm{r}$. W związku z tym ostatnio obserwowano wycofywanie się banków, takich jak Goldman Sachs, Morgan Stanley lub JP Morgan, z rynków towarowych.

Regulacje prawne, tj. EMIR ${ }^{15}$, MiFID II ${ }^{16}$, REMIT $^{17}$, wymuszają również na uczestnikach rynku automatyzację procesu handlowego, m.in. ze względu na wymóg transparentności informacji. Handel za pomoca systemu, który raportuje składane zlecenia i zawarte transakcje, stanowi z jednej strony ułatwienie, a z drugiej - staje się niezbędny. Idąca za tym lepsza jakość informacji, a przede wszystkim wzrost ich liczebności, mierzony w terabajtach i petabajtach (np. dostęp do danych o położeniu statków, poziomie zapasów, dostępności mocy produkcyjnych i ich ubytków na rynku energii elektrycznej) sprawiaja, że maszyny mogą przeanalizować informację efektywniej i szybciej, podając trafniejszą rekomendację traderowi ${ }^{18}$.

\section{Rozwój technologii}

Algorytmiczny trading i rozwój technologii sa ze sobą nierozerwalnie powiązane. Na podstawie danych zawartych w tabeli 2 można jednak stwierdzić, że niezautomatyzowane składanie zleceń i indywidualne podejmowanie decyzji jest na rynkach mniej popularne wśród mniejszych inwestorów. Powodem tego mogą być oczywiście koszty stojące za budową sprawnego i efektywnego automatu transakcyjnego, które można uznać za silną barierę wejścia. Wśród kosztów rozbudowanego systemu transakcyjnego należy wymienić:

- koszt zatrudnionych programistów,

- koszt dostępu do danych online,

- koszt współdzielenia serwerów i kolokacji z giełdami,

- koszt współdzielenia linii. 2010.

${ }^{12}$ Basel III, A global regulatory framework for more resilient banks and banking systems,

${ }^{13}$ Dodd-Frank Act, Dodd-Frank Wall Street reform and Consumer protection act, 2010.

${ }_{14}$ A. Ray, http://wealthandcapitalmarketsblog.celent.com/2014/05/30/big-banks-exodus-from-commodities/, 2014 [dostęp: 15.11.2016].

${ }_{15}$ EMIR, Regulation (EU) No 648/2012 on OTC derivatives, central counterparties and trade repositories (EMIR), 2012.

${ }^{16}$ MiFID II, Directive 2004/39/EC and the Regulation on Markets in Financial Instruments, 2014.

${ }^{17}$ REMIT, Rozporzqdzenie Parlamentu Europejskiego i Rady (UE) Nr 1227/2011 z dnia 25 października 2011 r. w sprawie integralności i przejrzystości hurtowego rynku energii (REMIT), 2011.

18 The Boston Consulting Group, op. cit. 
Jak pokazuja statystyki, globalne wydatki na infrastrukturę sięają wielu miliardów dolarów ${ }^{19}$. Tutaj doskonałym przykładem jest transatlantycki światłowód pomiędzy Londynem a Nowym Jorkiem - Hibernia Express, który od połowy 2015 r. umożliwia komunikację pomiędzy kontynentami w czasie o 10\% krótszym, czyli o 2,6 milisekundy. Linia kosztowała 300 milionów dolarów. Pełne omówienie tego aspektu wykracza jednak znacznie poza ramy przedmiotowego artykułu.

Wykres 3

Wydatki na infrastrukturę (w mln USD)

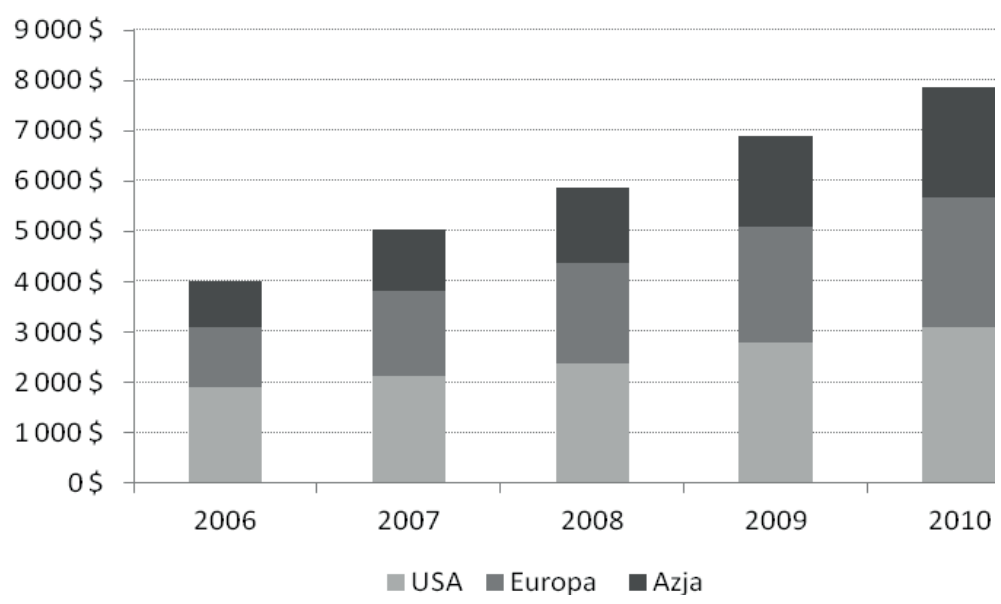

Źródło: opracowanie własne na podstawie danych B. Bailey²0.

\section{STRATEGIE WSPIERAJĄCE PROCES HANDLOWY - AUTOMATYCZNY HANDEL}

Strategie są najsilniej strzeżoną tajemnicą spółek tradingowych. Jednakże szczególnie wśród publikacji amerykański regulatorów można znaleźć wiele cennych informacji na ich temat.

Zgodnie z raportem The TABB Group ${ }^{21}$ firmy kupujace kontrakty terminowe za pośrednictwem brokerów korzystają głównie z prostych strategii in-

${ }^{19}$ M. Hudak, High Frequency Trading, International Markets, and Regulation, Carnegie Mellon University 2015, s. 1-42.

${ }^{20}$ B. Bailey, High-Performance Trading Infrastructure: Cost, Opportunities and Challenges, http://aitegroup.com/report/high-performance-trading-infrastructure-cost-opportunities-andchallenges, 2008 [dostęp: 30.11.2016].

${ }^{21}$ M. Simon, Algos in Futures Markets: Shifting into High Gear, The TABB Group 2014, s. $1-15$. 
westycyjnych. Można do nich zaliczyć strategie Stop, Iceberg oraz Market on Open/Close, czyli strategie aktywujace zlecenia przy danym poziomie ceny, dzielące zlecenia na mniejsze części, zawierajace transakcje na otwarciu lub zamknięciu sesji. Odpowiadają one za ponad 60\% transakcji na rynkach terminowych, jak pokazuje tabel 3 .

Tabela 3

Algorytmiczne strategie i ich oszacowany udział w rynku

\begin{tabular}{|l|l|c|}
\hline \multicolumn{1}{|c|}{ Strategie } & \multicolumn{1}{|c|}{ Przykłady } & Oszacowany udzial \\
\hline Proste & $\begin{array}{l}\text { Stop, Iceberg, Market on open/close } \\
\text { (MOO/C) }\end{array}$ & $60-70 \%$ \\
\hline $\begin{array}{l}\text { Benchmarkowe z harmo- } \\
\text { nogramem }\end{array}$ & $\begin{array}{l}\text { VWAP, TWAP, Arrival price, Implementa- } \\
\text { tion Shortfall }\end{array}$ & $10-20 \%$ \\
\hline Syntetyczne & $\begin{array}{l}\text { POV, powracanie do średniej, mechaniczne } \\
\text { (np. Iceberg) }\end{array}$ & $5-10 \%$ \\
\hline Wielorynkowe & $\begin{array}{l}\text { spready kalendarzowe, spready motyla, } \\
\text { pairs trading }\end{array}$ & $<5 \%$ \\
\hline Szukające płynności & $\begin{array}{l}\text { algorytmy ilościowe dostarczające lub ko- } \\
\text { rzystające z płynności, Hide/seek }\end{array}$ & $<5 \%$ \\
\hline Spersonalizowane & utworzone na specjalne zamówienie & $<1 \%$ \\
\hline
\end{tabular}

Źródło: opracowanie własne na podstawie badań M. Simon, op. cit.

Pozostałe kategorie strategii, to głównie:

- VWAP (Volume weighted average price), algorytmy partycypujace w wolumenie obrotu na danej sesji, który jest prognozowany na podstawie danych historycznych;

- TWAP (Time weighted average price), algorytmy realizujące zlecenia ze stałym udziałem w czasie trwania sesji;

- POV (Percentage of volume), zapewniające stały procent uczestnictwa w wolumenie obrotu;

- Arrival Price i Implementation Shortfall - stosowane rozwiązania różnia się w zależności od brokera i dostawcy systemu. Najczęściej na podstawie zadanego poziomu akceptacji ryzyka i szybkości czasu realizacji zleceń algorytm tworzy prognozowany harmonogram/trajektorię realizacji transakcji (benchmark), dążąc do minimalizacji różnicy pomiędzy ceną decyzji (arrival price) a rzeczywistą ceną realizacji zlecenia ${ }^{22}$.

Poza wymienionymi strategiami warto wspomnieć o algorytmach poszukujących płynności - liquidity-seeking algos, które reagują na warunki rynkowe, gromadzą charakterystyki wolumenu obrotu danym produktem na danej giełdzie. W'śród podobnych strategii znaleźć można też Smart order routers (SOR),

${ }^{22}$ R. Kissell, The Science of Algorithmic Trading and Portfolio Management, Elsevier 2014, s. $17-19$. 
które agregują płynność pomiędzy różnymi miejscami handlu łącznie z dark poolami ${ }^{23}$.

Wymienione strategie, które w różnym stopniu opierają się na działaniu algorytmów, można zakwalifikować do kategorii automatycznych strategii optymalizujacych proces handlowy. Z uwagi na przedmiot badania artykułu konieczne jest jednak bardziej wnikliwe spojrzenie na algorytmiczne strategie inwestycyjne.

\section{STRATEGIE WYMAGAJĄCE INWESTYCJI TECHNOLOGICZNYCH - ALGORYTMICZNY HANDEL}

Skuteczne algorytmy mogą łączyć zarówno elementy strategii klasycznych, jak również obejmować wielopłaszczyznową analizę międzyrynkową (choćby ze względu na opisywaną wcześniej finansyzację), analizę dużej ilości napływajacych danych zarówno rynkowych, jak również makroekonomicznych, czy po prostu opierać się na dużej liczbie zawieranych transakcji. Wśród mnogości stosowanych metod wyłania się grupa o najbardziej zaawansowanych rozwiazaniach, wymagajaca opisywanych w punkcie 2.4 inwestycji technologicznych.

\section{Handel wysokiej częstotliwości}

Handel wysokiej częstotliwości (High Frequency Trading, popularnie określany skrótem HFT) to oparty na algorytmach ultraszybki handel z atomowym czasem podejmowania decyzji. W ostatnich latach zyskał popularność lub raczej złą sławę ze względu na stosowanie praktyk i metod prowadzących do nadużyć rynkowych.

Algorytmy HFT swoją efektywność opierają na szybkości przetwarzania i analizowania ogromnych zbiorów danych w bardzo krótkim czasie, jak i szybkim dostępie do danych i serwerów giełdy. Ponieważ szybkość przesyłania danych podlega podstawowym prawom fizyki, do których można zaliczyć prędkość rozchodzenia się światła, serwery, na których działają programy tradingowe, zlokalizowane w okolicach giełd, zyskuja przewage milisekundowa, a czasem nawet sekundowa. Prędkość rozchodzenia światła w próżni jest równa 299792,458 km/s, jednak m.in. ze względu na współczynnik załamania w szkle, w rzeczywistości opóźnienie jest szacowane na 0,82 milisekundy na $160,9 \mathrm{~km}^{24}$. Algorytmy HFT służą głownie analizowaniu poziomów cen i pozycji w czasie trwania sesji. Zazwyczaj transakcje sa optymalizowane w trakcie trwania sesji, bez pozostawiania otwartej pozycji na kolejny dzień. Mogą łączyć dużo różnych strategii, jednak głównym ich wyróżnikiem względem pozostałych algorytmów sa: szybkie otwieranie i zamykanie pozycji (nawet w czasie

${ }^{23}$ M. Simon, op. cit., s. 5-6.

${ }^{24}$ CISCO, Design Best Practices for Latency Optimization, CISCO 2007, s. 1. 
sekundy i ułamka sekundy), wysoki procent zleceń anulowanych do zrealizowanych oraz szybkość i częstotliwość składania zleceń i realizacji transakcji ${ }^{25}$.

Strategie HFT można podzielić na dwie grupy: pasywne i aktywne. Do pasywnych algorytmów należy zaliczyć pasywny market making, który dostarcza płynności rynkowi. Zlecenia znajdujące się po dwóch stronach rynku w określonym spreadzie muszą być stale aktualizowane ze względu na zmieniajace się warunki rynkowe. Firmy wdrażające tego rodzaju strategie często zarabiają również na obniżonych opłatach handlowych ${ }^{26}$.

Do wymienionej grupy zaliczyć można strategie arbitrażowe, które nie biorą pod uwagę kierunkowych ruchów, lecz zależą od kointegracji i korelacji cen. Jedną z najbardziej znanych metodyk jest rozwinięta przez pracowników Morgan Stanley już w latach osiemdziesiątych XX w. - pairs trading, która przynosi bankowi niemal co roku zyski. Straty odnotowane były jedynie w ciągu kilku lat jej stosowania. Strategia polega na zawieraniu pozycji długiej (kupowaniu) jednego produktu lub terminu zapadalności kontraktu i pozycji krótkiej (sprzedawaniu) innego produktu/kontraktu przy zadanej wcześniej proporcji. Technika ta jest często stosowana na rynku ropy naftowej, gdzie poziom zmienności często zakłóca normalną relację pomiędzy cenami różnych rodzajów ropy np. Brent i West Texas Oil ${ }^{27}$.

Niezwykle ciekawą i wzbudzajaccą często negatywne emocje kategorią strategii handlu o wysokiej częstotliwości są aktywne HFT. To właśnie w tej grupie można znaleźć taktyki karalne, naruszajace zasady handlu. Wśród najbardziej znanych należy wymienić:

- quote stuffing - których zadaniem jest tworzenie fałszywych poziomów cenowych przez zalewanie rynku zleceniami, które są bardzo szybko anulowane;

- spoofing - algorytmy, którym przypisuje się występowanie zjawisk zwanych Flash Crash, czyli szybkich załamań cen na rynkach. Trader, który używa tej techniki, podobnie jak w poprzedniej strategii, zalewa rynek zleceniami kupna lub sprzedaży, powodując przesuwanie się zleceń innych uczestników rynku. Algorytm zawiera transakcję w przeciwstawnym kierunku do pierwotnie składanego zlecenia, zyskując na lepszej cenie.

- predatory algorithms (sharks) - algorytmy te ustawicznie sprawdzają rynek, poszukując ceny rynkowej dużego zlecenia, powodując jej przesuwanie ${ }^{28}$.

\section{Strategie oparte na napływających informacjach}

Na bardzo płynnych rynkach decyzje inwestycyjne podejmowane są w skali mikrosekund. Opóźnienie rzędu kilku sekund rozpatrywane jest jako strata na poziomie kilku procent kapitału. Niestety nie wszyscy uczestnicy rynku

${ }^{25}$ C. Heumesser, C. Staritz, op. cit., s. 1-61.

${ }^{26}$ SEC, Equity Market Structure Literature Review Part II: High Frequency Trading, SEC 2014, s. 1-37.

${ }^{27}$ C. Lim, High Frequency Trading of Brent Crude Price, „International Journal of Management Sciences and Business Research" 2(8), 2013, s. 14-18.

${ }^{28}$ M. Hudak, op. cit., s. 1-42. 
mają dostęp do informacji w takim samym czasie. Według badań z rynku kapitałowego przeprowadzonych przez Martina Scholtusa, Dicka van Dijka i Barta Frijnsa ${ }^{29}$ nad wpływem publikacji danych makroekonomicznych na wyniki handlu na State Street S\&P500 Exchange Traded Fund, notowanym na NASDAQ, opóźnienie 1 sekundy skutkuje utratą 7,33\% całkowitego zysku.

Oprócz szybkości podejmowania decyzji ważne jest również właściwe oszacowanie jej wpływu. I tu w ostatnich latach wypracowano nowe rozwiązania technologiczne. Wiele serwisów, tj. Bloomberg czy Reuters, dostarcza strumienie danych ze zdigitalizowanymi wiadomościami opatrzonymi dodatkowymi atrybutami, które ułatwiają analizę nawet miękkich aspektów informacji, tj. ważność, efekt zaskoczenia, sentyment rynkowy. Dzięki takim rozwiąaniom traderzy mogą wdrażać własne ultraszybkie algorytmy reagujace na bieżace wydarzenia na rynku bez potrzeby analizy ogromnej liczby dostępnych infor$\operatorname{macji}^{30}$.

\section{ZNACZENIE AUTOMATYCZNEGO HANDLU NA RYNKACH SUROWCÓW}

Wykorzystywanie na rynkach strategii inwestycyjnych opartych na algorytmach, które w krótkim czasie analizują napływające na rynek dane i na ich podstawie podejmują decyzje inwestycyjne, prowadzi do wzrostu efektywności rynku. Można bowiem oczekiwać, że dobrze skalibrowane systemy będa przetwarzać każdy istotny sygnał na odpowiednią decyzję inwestycyjna. Nieracjonalność inwestorów ${ }^{31}$ obserwowana na rynkach, na których przewage maja inwestorzy podejmujacy decyzje samodzielnie, przestanie zatem odgrywać istotną rolę w kształtowaniu cen. W związku z tym długookresowe niedowartościowanie i przewartościowanie instrumentów na rynkach, opisane pierwszy raz przez Benjamina Grahama i Davida Dodda w 1934 r. ${ }^{32}$, ale analizowane również w pracach Karima Abadira i Gabriela Talmaina ${ }^{33}$, powinno stopniowo zanikać wraz ze wzrostem popularności algorytmicznego tradingu.

$\mathrm{Na}$ podstawie powyższych założeń handlu automatycznego łatwo stwierdzić, że nieodzownym następstwem rozwoju algorytmicznego handlu jest wyeliminowanie czynnika ludzkiego w procesie podejmowania decyzji inwestycyjnych. Jak pokazują statystyki, stosowane dotychczas z powodzeniem proste strategie handlowe nie są do końca zyskowne. Zautomatyzowane CTA - Commodity Trading Advisor - fundusze hedgingowe, które w 85\% stosuja

${ }^{29}$ M. Scholtus, D. Dijk, B. Frijns, Speed, algorithmic trading, and market quality around macroeconomic news announcements, „Journal of Banking \& Finance” 38, 2014, s. 89-105.

${ }^{30}$ S. Borovkova, A. Lammiman, The impact of News Sentiment on Energy Futures Returns, Vrije Universiteit Amsterdam 2010, s. 1-10.

31 A. Szyszka, Finanse behawioralne. Nowe podejścu od inwestowania na rynku kapitałowym, Wyd. UE, Poznań 2009, s. 9 i 15-16.

32 B. Graham, D. Dodd, Security Analysis, Whittlesey House, McGraw-Hill Book Co. 1932.

${ }^{33}$ K. Abadir, G. Talmain, Distilling co-movements from persistent macro and financial series, Working Paper Series 525/2005, s. 1-38. 
wyłącznie strategie kierunkowe, w ostatnich latach przynosiły straty ${ }^{34}$. Znajomość różnych strategii, różnych mechanizmów napędzanych ultraszybkimi technologiami jest niezbędna, by prawidłowo odróżnić zmiany fundamentalne na rynku od chwilowych wahań.

Jednym ze skutków działania algorytmów na rynkach jest zatem konieczność poszukiwania nowych czynników kształtujących ceny notowanych instrumentów, a w konsekwencji pojawienie się odmiennych możliwości wypracowywania dodatnich stóp zwrotu na rynkach. Stanowi to jednak ogromne wyzwanie ze względu na bariery kosztowe, technologiczne, informatyczne, a także regulacyjne, by zastosować odpowiedni i efektywny algorytm, czy strategię algorytmiczna, która byłaby w stanie nie tylko wesprzeć proces handlu, ale przede wszystkim nie przynosić strat, a wręcz pobić rynek.

\section{PODSUMOWANIE}

Postępująca automatyzacja handlu hurtowego wprowadziła zmiany strukturalne na rynku towarowym. Z przedstawionych analiz wynika, że zwiększone poziomy wolumenu obrotu, otwartych pozycji, zwiększona płynność, krótkookresowe odchylenia od długookresowej fundamentalnej ścieżki poziomów cen, wydłużone czasy trwania aktywnych sesji, są efektem działań inwestorów finansowych i potwierdzają obecność technik stosowanych na rynkach finansowych.

Stopień automatyzacji determinuje typ towaru. Ustawiczny rozwój rynków, a szczególnie ich płynności, zmienia jednak ten poziom. Stopień wykorzystania metod może być również różny ze względu na cel optymalizacyjny: począwszy od klasycznych metod ułatwiających maksymalizację zyskowności realizacji zleceń i zarządzanie ich ryzykiem, tj. VWAP, TWAP, Implementation Shortfall, po strategie dajace dodatkowe zyski z handlu spreadowego, a także rozwój technologii wspierającej szybkość podejmowania decyzji.

mgr Monika Piaskowska

Uniwersytet Ekonomiczny w Poznaniu

monikapiaskowska@wp.pl

\section{AUTOMATED TRADING IN COMMODITY MARKETS}

Sum mary

In the paper we analyse structural changes in commodity markets, their financialisation and consequently growing automation. The main factors which foster the development of algorithmic trading are explained and the common methods and strategies used in trading processes and required investments in technology reviewed.

${ }^{34}$ Financial Times, https://www.ft.com/content/9df7ccec-dcc4-11e5-827d-4dfbe0213e07 [dostęp: 28.11.2016]. 